\title{
Maintenance Organization at Universiti Tun Hussein Onn Malaysia (UTHM)
}

\author{
Mohd Norazam bin Yasin ${ }^{1, a}$, Abd Halid Abdullah ${ }^{2, b}$ Fajaruddin mustakim ${ }^{3, c}$ \\ Bachan Singh ${ }^{4, d}$ Abd. Rahim Abd. Hamid ${ }^{5, e}$ \\ ${ }^{1,2,3}$ Faculty of Civil and Environmental Engineering, Universiti Tun Hussein Onn Malaysia \\ ${ }^{4,5}$ Faculty of Civil Engineering, University of Technology Malaysia \\ anorazam@uthm.edu.my, babdhalid@uthm.edu.my, ${ }^{\mathrm{c}}$ fajardin@uthm.edu.my, \\ dbachan19@yahoo.com, rahimfka@yahoo.com
}

Keywords: Maintenance, Life span, Organization, Training, Job satisfaction, UTHM

\begin{abstract}
Proper maintenance of buildings is to extend the life span of buildings [1]. In order to maintain the buildings, apart from maintenance work, is the organization aspect, one of the important elements in building maintenance [3]. The organization will have to be carefully structured and designed so that the staff can function efficiently $[8,9,10,11,13]$. The staff will have to be given training from time to time so that they are acquainted with the current technology and to tackle the challenges $[6,12]$. The objectives of this study are to examine the current maintenance organizational structure, to identify the main problems faced by the maintenance staff, to evaluate the level of job satisfaction and to identify the types of training to be provided to the maintenance staff. The study is carried through questionnaires and interviews. A total of fifty (50) questionnaires are distributed to the respondents consisting of engineers, technical assistants and technicians. The data is analyzed using average index. From the study, it was found that the type of organization structure of the maintenance department in UTHM is of line and staff.
\end{abstract}

\section{Introduction}

Maintenance is an important feature of any structure. According to Ahmad (2002) maintenance is always a must for any structure in order to maintain is serviceability and to prevent deterioration that may shorten the service life [1,2]. Proper maintenance of the buildings is very important and need to be given top priority by the organization. Maintenance, as per British Standard 3811 is defined as 'the combination of all technical and administrative actions intended to retain an item in, or restore it to, a state in which it can perform its required function' [4,5]. According to Harold Koontz (1955) was described organization as 'people working together in groups to achieve some goal must have roles to play, much like the parts actors fill the drama, whether these roles are ones they develop themselves, are accidental or haphazard, or are defined and structured by someone who wants to make sure that people contribute in a specific way to group effort' $[8,9,10,11]$.

\section{Problem Statement}

With the aging of some of the buildings which are approximately 30 years ever since it were being constructed UTHM faces problems in building maintenance. The budget obtained from the Ministry of Education (MOE) is not enough for the yearly maintenance. Are there various mechanisms for the maintenance department to forecast the yearly budget? Can the maintenance department justify the priority of works to be carried out? UTHM also spends too much money to carryout repair works as some of the defects reoccur even though the repair works have been carried out. The maintenance staff faces problems repairing these recurring problems due to some of the problems due to design failure. Apart from the budget, the maintenance department faces many challenges as the campus expands rapidly. The sudden change involves the staff and the organization itself. The staff will have to be trained to handle the influx of maintenance work. The staff were not given the job description and job specification when they employed by UTHM. They are just provided with the contract of employment and most of the training for the staff is on the job 
training. Therefore, the training provided to the staff is adequate enough for them to carry out the work efficiently and effectively? The organization structure by itself also influence the way the department runs the maintenance. Poor organization will result in slower response time, more red tapes and this will eventually affect the completion of the repair works. Does the organization need to be restructured? Are the employees qualified enough to manage and carryout the repair works? Are the maintenance staffs highly motivated and productive in carrying out the maintenance work?

\section{Aim and Objectives}

The aim of this study is to examine the maintenance department and the job satisfaction of the maintenance staff.

- To examine the current maintenance organizational structure

- To identify the main problems faced by the maintenance staff

- To evaluate the level of job satisfaction of maintenance staff

- To identify the types of training to be provided to the maintenance staff

\section{Organization Structure}

Organization structure is the formal pattern of interactions and coordination designed to link the task of individuals and groups to achieve organizational goals. The word 'formal' is refer to the point at which organization structure was created by the management to achieve organizational goals and objectives and hence, is official or formal outcomes of the organizing function [13]. Organizations are also having informal structures or patterns of interaction, which is not designed by management but emerging because of common interests or friendships. The process of developing an organization structure is referred to as organization design $[9,10,13]$.

\section{Job Satisfaction}

Locke $(1969,1976)$ defined job satisfaction as "a pleasurable or positive emotional state resulting from the appraisal of one's job or job experiences" [6,7]. In simple terms, job satisfaction explains; what makes people want to come to work and what makes them happy about their job in order for them not to quit their job? It is found in many researches that Job Satisfaction can lead to Intention to stay in an organization (Kim et al., 1996) [7]. An important finding for organizations to note is that job satisfaction has a rather tenuous correlation to productivity on the job [12]. Job satisfaction is important to an organization's success [12].

\section{Training}

According to Wexley \& Latham (1981); Hall \& Goodale (1986); Bateman \& Zeithaml (1990) the term of training and development is defined as a planned effort to facilitate employee learning of job- related behavior to improve performance [12]. Whereas training is an attempt to improve employee performance on current job, development is learning opportunities designed to help employees grow.

\section{Methodology}

Primary information was obtained by collecting data from the archive of Pejabat Pembangunan \& Pengurusan Hartabina, UTHM. Secondary information was obtained from questionnaires survey and interview. The questionnaires survey was carried out to the maintenance staff at UTHM. The interview session is to get the information of the maintenance organization. Information obtained from primary and secondary sources was analyzed and processed to get the final results of the study. All information and theories gather from secondary information was applied to the primary information to test the accuracy of the theory. After getting the final results, a conclusion and recommendation was done. 


\section{Data Analysis}

Table 1 shows the list of problem faces by maintenance staff contents and the mean index for each element according to the survey has been done in maintenance department at UTHM. The table shows that client do not understand about the maintenance work process was score the highest mean index 3.42. The second score was for inadequate budget 3.39. The third score was for understaffed 3.34. Followed by uncomfortable workplace 3.24, lack of materials, equipment and tools 3.11, lack of training 3.05, unsatisfied client feedback 3.03, maintenance staff is always scolded by the client also 3.03. The least score was lack of commitment 2.39 . To get clear view about this we can look to Figure 1 below.

\section{Table 1. Problem Faces by Maintenance \\ Staff}

\begin{tabular}{|c|c|c|c|c|c|c|}
\hline \multirow{3}{*}{$\begin{array}{l}\text { Problem Faces by } \\
\text { Maintenance Staff }\end{array}$} & \multirow{2}{*}{\multicolumn{5}{|c|}{$\begin{array}{c}\text { Number of } \\
\text { Respondents }\end{array}$}} & \multirow{3}{*}{ Mean } \\
\hline & & & & & & \\
\hline & 1 & 2 & 3 & 4 & 5 & \\
\hline 1) Job description unclear & 1 & 15 & 15 & 7 & 0 & 2.74 \\
\hline 2) Job specification unclear & 1 & 18 & 12 & 7 & 0 & 2.66 \\
\hline 3) Lack of knowiedge & 2 & 14 & 16 & 5 & $\mathrm{I}$ & 2.71 \\
\hline 4) Lack of training & 2 & 9 & 14 & 11 & 2 & 3.05 \\
\hline 5)Lack of skill & 1 & 14 & 18 & 3 & 2 & 2.76 \\
\hline 6) Lack of experience & 2 & 12 & 16 & 7 & 1 & 2.82 \\
\hline 7) Lack of communication & 2 & 15. & 15 & 5 & 1 & 2.68 \\
\hline 8$)$ Lack of commitment & 3 & 18 & 9 & 5 & I & 2.39 \\
\hline $\begin{array}{l}\text { 9)Lack of materials, } \\
\text { equipment and tools }\end{array}$ & 1 & 13 & 10 & 9 & 5 & 3.11 \\
\hline 10) Unclear instructions & 3 & 13 & 19 & 3 & 0 & 2.58 \\
\hline 11) Linderstafted & 1 & 6 & 15 & 11 & 5 & 3.34 \\
\hline $\begin{array}{l}\text { 12) Inadequate budget for } \\
\text { Training and advancement }\end{array}$ & 0 & 5 & 17 & 12 & 4 & 3.39 \\
\hline $\begin{array}{l}\text { 13) Lncomfortable } \\
\text { workplace }\end{array}$ & 1 & 10 & 11 & 11 & 5 & 3.24 \\
\hline $\begin{array}{l}\text { 14) Not acceptability of } \\
\text { completed work }\end{array}$ & 1 & 14 & 17 & 6 & 0 & 2.74 \\
\hline $\begin{array}{l}\text { 15)lnability to organize and } \\
\text { schedule workloads }\end{array}$ & 2 & 11 & 18 & 7 & 0 & 2.79 \\
\hline $\begin{array}{l}\text { 16) Unwillingness to perform } \\
\text { duties }\end{array}$ & 4 & 15 & 13 & 5 & 1 & 2.58 \\
\hline $\begin{array}{l}\text { 17) Improper preparation of } \\
\text { documentation and drawing }\end{array}$ & 1 & 14 & 12 & 10 & I & 2.89 \\
\hline $\begin{array}{l}\text { 18) Unsatisfied client } \\
\text { feedback }\end{array}$ & 0 & 10 & 19 & 7 & 2 & 3.03 \\
\hline $\begin{array}{l}19 \text { Client do not understand } \\
\text { about the maintenance work } \\
\text { process }\end{array}$ & 2 & 8 & 8 & 12 & 8 & 3.42 \\
\hline $\begin{array}{l}\text { 20)Maintenance staff is } \\
\text { always scolded by the client }\end{array}$ & 3 & 8 & 15 & 9 & 3 & 3.03 \\
\hline
\end{tabular}

Table 2. Level of Job Satisfaction

\begin{tabular}{|c|c|c|c|c|c|c|}
\hline \multirow{2}{*}{ Level of Job Satisfaction } & \multicolumn{5}{|c|}{$\begin{array}{l}\text { Number of } \\
\text { Respondents }\end{array}$} & \multirow[t]{2}{*}{ Mean } \\
\hline & 1 & 2 & 3 & 4 & 5 & \\
\hline $\begin{array}{l}\text { 1)During the interview, } 1 \\
\text { am told about my position } \\
\text { and duties }\end{array}$ & 1 & 8 & 10 & 15 & 4 & 3.34 \\
\hline $\begin{array}{l}\text { 2) The job specification is } \\
\text { clear }\end{array}$ & 3 & 10 & 15 & 8 & 2 & 2.89 \\
\hline $\begin{array}{l}\text { 3) Currently, I am satisfied } \\
\text { with my work }\end{array}$ & 0 & 6 & 12 & 13 & 7 & 3.55 \\
\hline $\begin{array}{l}\text { 4) l am satisfied with my } \\
\text { supervisor }\end{array}$ & 2 & 14 & 12 & 6 & 4 & 2.89 \\
\hline $\begin{array}{l}\text { 5)My relationship with my } \\
\text { co-worker are good }\end{array}$ & 2 & 15 & 10 & 8 & 3 & 2.87 \\
\hline $\begin{array}{l}\text { 6)1 understand my work } \\
\text { thoroughly }\end{array}$ & 3 & 15 & 10 & 7 & 3 & 2.79 \\
\hline 7)I seldom take leave & 0 & 3 & 16 & 13 & 6 & 3.58 \\
\hline 8)I view my job seriously & 0 & 0 & 8 & 16 & 14 & 4.16 \\
\hline $\begin{array}{l}\text { 9)I am satisfied with the } \\
\text { trainings provided }\end{array}$ & 3 & 8 & 15 & 9 & 3 & 3.03 \\
\hline $\begin{array}{l}\text { 10) The salary commensurate } \\
\text { with my work }\end{array}$ & 1 & 9 & 13 & 13 & 2 & 3.16 \\
\hline $\begin{array}{l}\text { 11)I am satisfied with } \\
\text { working hours }\end{array}$ & 1 & 14 & 10 & 10 & 3 & 3.00 \\
\hline $\begin{array}{l}\text { 12) I am satisfied with } \\
\text { working conditions }\end{array}$ & 2 & 11 & 8 & 14 & 3 & 3.13 \\
\hline $\begin{array}{l}\text { 13)l am satisfied with the } \\
\text { benefits that } 1 \text { got }\end{array}$ & 1 & 4 & 15 & 14 & 4 & 3.42 \\
\hline $\begin{array}{l}\text { 14)1 am aware of new } \\
\text { development and technology } \\
\text { related to my job }\end{array}$ & 0 & 0 & 8 & 25 & 5 & 3.92 \\
\hline $\begin{array}{l}\text { 15)1 observance of rest and } \\
\text { lunch periods }\end{array}$ & 0 & 10 & 16 & 10 & 2 & 3.11 \\
\hline $\begin{array}{l}\text { 16) I am satisfied with job } \\
\text { security }\end{array}$ & 2 & 7 & 10 & 17 & 2 & 3.26 \\
\hline $\begin{array}{l}\text { 17) } 1 \text { don t have any problem } \\
\text { work in the different team or } \\
\text { personnel of maintenance } \\
\text { organization }\end{array}$ & 0 & 1 & 8 & 21 & 8 & 3.95 \\
\hline $\begin{array}{l}\text { 18)I don't have any problem } \\
\text { to work in the new proposed } \\
\text { of maintenance organization }\end{array}$ & 0 & 10 & 8 & 13 & 7 & 3.45 \\
\hline $\begin{array}{l}\text { 19)Staft's are expected to } \\
\text { follow their own personal } \\
\text { and morale belief }\end{array}$ & 0 & 1. & 20 & 14 & 3 & 3.50 \\
\hline $\begin{array}{l}\text { 20)Management should take } \\
\text { note of the stafts achievement } \\
\text { and sacrifice }\end{array}$ & 0 & 0 & 8 & 19 & 11 & 4.08 \\
\hline \multicolumn{7}{|l|}{$\begin{array}{l}21) \text {, am given the } \\
\text { responsibility to; }\end{array}$} \\
\hline a) Make decision & 1 & 10 & 15 & 7 & 5 & 3.13 \\
\hline b) Planning and & 2 & 3 & 5 & 24 & 4 & 3.66 \\
\hline $\begin{array}{l}\text { c) Controlling my own job } \\
\text { independently }\end{array}$ & I & 9 & 20 & 6 & 2 & 2.97 \\
\hline
\end{tabular}




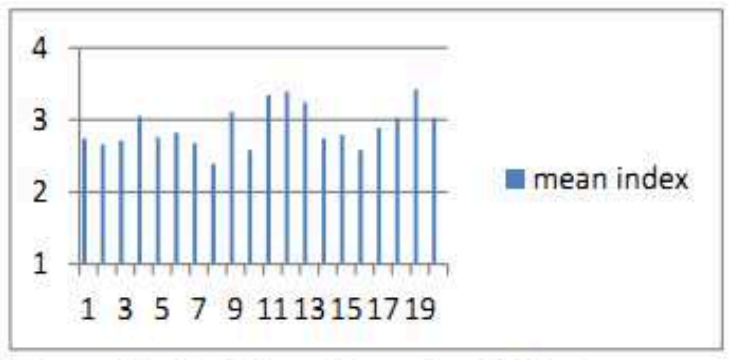

Figure 1. Problem Faces by Maintenance Staff

Table 3. Training and types of training 1-Totally Disagree 5-Totally Agree

\begin{tabular}{|c|c|c|c|c|c|c|}
\hline \multirow{2}{*}{ Training } & \multicolumn{5}{|c|}{$\begin{array}{c}\text { Number of } \\
\text { Respondents }\end{array}$} & \multirow[t]{2}{*}{ Mean } \\
\hline & 1 & 2 & 3 & 4 & 5 & \\
\hline $\begin{array}{l}\text { 1) Continuous learning is staffs } \\
\text { own responsibility }\end{array}$ & 0 & 2 & 7 & 23 & 6 & 3.87 \\
\hline $\begin{array}{l}\text { 2)The training did you attended } \\
\text { is relevant to your job }\end{array}$ & 0 & 0 & 5 & 24 & 9 & 4.11 \\
\hline $\begin{array}{l}\text { 3)The training that you attending } \\
\text { give benefit to the organization }\end{array}$ & 0 & 0 & 3 & 25 & 10 & 4.18 \\
\hline $\begin{array}{l}\text { 4)The staff need to discuss with } \\
\text { The supervisor the relevant } \\
\text { training that he/she should attend }\end{array}$ & 0 & 1 & 5 & 25 & 7 & 4.00 \\
\hline $\begin{array}{l}\text { 5)Organization should provide } \\
\text { the suitable training to the staff } \\
\text { based on their job or expertise }\end{array}$ & 0 & 0 & 4 & 19 & 15 & 4.29 \\
\hline $\begin{array}{l}\text { Types of training required } \\
\text { 6)Planning \& Scheduling }\end{array}$ & 0 & 0 & 4 & 18 & 16 & 4.32 \\
\hline 7)Maintenance technology & 0 & 0 & 1 & 19 & 18 & 4.45 \\
\hline $\begin{array}{l}\text { 8) Supervision of maintenance } \\
\text { work }\end{array}$ & 0 & 0 & 0 & 15 & 23 & 4.61 \\
\hline 9)Contract administration & 0 & 0 & 7 & 18 & 13 & 4.16 \\
\hline 10)Maintenance management & 0 & 0 & 3 & 17 & 18 & 4.39 \\
\hline 11)Communication skills & 0 & 0 & 4 & 19 & 15 & 4.29 \\
\hline $\begin{array}{l}\text { 12) Trade skill (carpentry, } \\
\text { bricklayer etc.) }\end{array}$ & 0 & 0 & 7 & 17 & 14 & 4.18 \\
\hline
\end{tabular}

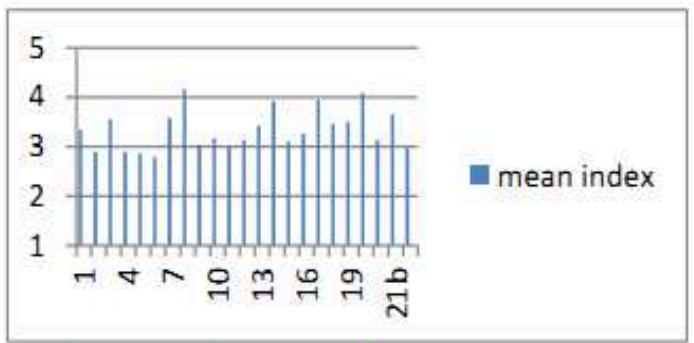

Figure 2. Level of job satisfaction

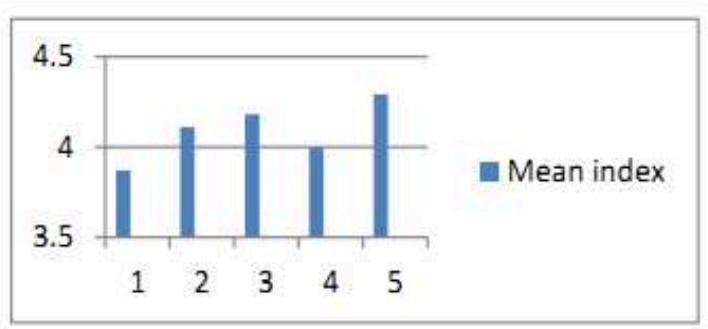

Figure 3. Training

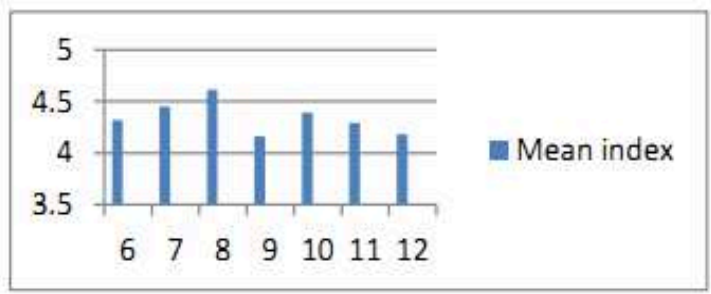

Figure 4. Types of training

Table 2 shows the list of level of job satisfaction contents and the mean index for each element according to the survey has been done in maintenance department at UTHM. The table shows that I view my job seriously was scoring the highest mean index 4.16. The second score was for management should take note of the staffs achievement and sacrifice 4.08. The third score was for currently, I don't have any problem work in the different team or personnel of maintenance organization 3.95. The least score was the, I understand my work thoroughly 2.79. To get clear view about this we can look to Figure 2 above. Table 3 above shows the list of training and types of training contents and the mean index for each element. For the training mean index, the table shows that Organization should provide the suitable training to the staff based on their job or expertise was score the highest mean index 4.29. The second score was for the training that you attending give benefit to the organization 4.18. The third score was for the training did you attended is relevant to your job 4.11. The least score was continuous learning is staffs own responsibility 3.87. To get clear view about this we can look to Figure 3 above. For the types of training mean index, the table shows that supervision of maintenance work was score the highest mean index 4.61. The second score was for maintenance technology 4.45. The third score was for maintenance management 4.39. The least score was contract administration 4.16. To get clear view about this we can look to Figure 4 above. 


\section{Conclusion}

From the study, it was found that the organizational structure is of line and staff. The organizational structure is tall organization because it has many level of authority relative to the organization's size. There is a "long chain of command" running from the top of the organization down to the bottom of the organization. It's also known as pyramidtype organization that has relatively large number of levels in its hierarchy of authority. As level in hierarchy increase, communication will get difficult. Communication will become more garbled as it is repeated through the department. So as a result more time being taken to implement decisions. As an organization grows, the number of management levels increases and the structure grows taller. The main problems faced by the maintenance organization according to priority are client do not understand about the maintenance work process, inadequate budget for training and advancement, understaffed, uncomfortable workplace and lack of materials, equipment and tools. The level of job satisfaction of maintenance staff is 'Average Satisfied'. There are understanding the work, relationships with the co- worker, relationship with the supervisor, the job specification, responsibility to control the own job independently, working hours, the trainings provided, making decision, working conditions and salary. The types of training required that need to be provided are supervision of maintenance work, maintenance technology, maintenance management, planning \& scheduling and communication skills. Therefore, future studies can be carried out on maintenance organization involving government or private sectors. Based on findings, an approach can be recommended to assist management in maintenance organization.

\section{Acknowledgement}

Support from Department of Building and Construction Engineering, Faculty of Civil Environmental Engineering, Universiti Tun Hussein Onn Malaysia (UTHM) and Ministry of Education Malaysia (MOE).

\section{References}

[1] Barrie Chanter and Peter Swallow, Building Maintenance Management, $2^{\text {nd }}$ edition, De Montfort University, Leicester. (2007)

[2] Reginald Lee, M. Phil, FRICS, Building Maintenance Management, University of Reading, England. (1976)

[3] Gregory H. Magee, PE, Facilities Maintenance Management, Kingston. (1988)

[4] British Standard, Building Maintenance Management, BS 8210. (1986)

[5] Edward D Mills, CBE, FRIBA, FSIAD, Building Maintenance and Preservation- A Guide for Design and Management, London. (1980)

[6] Robert A. Suttermeister, People and Productivity, third edition, University of Washington. (1976)

[7] Mattew P. Stephens, Productivity and Reliability- Based Maintenance Management, New Jersey. (2004)

[8] Mathis \& Jackson, Human Resource Management- Essential Perspectives, third edition, Canada. (2005)

[9] John M. Ivancevich, Human Resource Management, $11^{\text {th }}$ edition, University of Houston. (2010)

[10] Ellen Ernst Kossek and Richard N. Block, Managing Human Resources in The $21^{\text {st }}$ CenturyFrom Core Concepts to Strategic Choice, Michigan State University. (2000)

[11] Harold Koontz and Heinz Weihrich, Management, ninth edition, USA. (1988)

[12] Adeniyi, O.I, Staff training and development in Ejiogu, A; Achumba, I. Asika (eds). (1995)

[13] Reading in Organizational Behavior in Nigeria, Lagos. Maltho use Press Ltd, Mondy, R.W. et al, Management and Organization Behavior. Boston, Allyn and Bacon Publishers. (1990) P 159- 167. 